DOI https://doi.org/10.30525/978-9934-588-63-1.06

\title{
ЕКСТРАДИЦІЯ ТА ПЕРЕДАЧА ОСІБ \\ МІЖНАРОДНИМ КРИМІНАЛЬНИМ ТРИБУНАЛАМ І СУДАМ: ПРОБЛЕМИ РОЗМЕЖУВАННЯ
}

\author{
Волощук О. Т., Колесник В. Ю.
}

\section{ВСТУП}

Як відомо, інститут екстрадиції із плином часу трансформувався під впливом багатьох чинників. Стрімкий розвиток співробітництва держав у минулому столітті, зокрема в питанні надання правової допомоги у кримінальних справах, створення разових міжнародних трибуналів (Нюрнберзький, Токійський, щодо колишнюої Югославії та Руанди), а пізніше - постійно діючої міжнародної судової установи - Міжнародного кримінального суду (далі - МКС), сприяло, природно, появі нових правил щодо порядку здійснення передачі осіб. Водночас процес взаємодії в питаннях екстрадиції між державами значно ускладнився і став сутєво відрізнятися від тих традиційних правил, що існували в міжнародній практиці до XX ст., а поява міжнародних судових установ, отже, i розширення сфери застосування даного інституту, потребує переосмислення екстрадиційних процесів 3 урахуванням сучасних тенденцій розвитку міжнародного кримінального права загалом та інституту міжнародної кримінальної юстиції зокрема.

Загалом, якщо звернутися до закордонної та вітчизняної юридичної науки, очевидно те, що інститут екстрадиції привертає увагу багатьох науковців. Зокрема, серед грунтовних досліджень західних учених варто виділити праці М. Бассіуні, С. Беді, К. Вінджерт, Г. Джилберта, А. Кассезе, М. Кардозо, Х. Лаутерпахта, Ф. Мартенса, М. Плачта, К. Пуле, А. Ширера й ін. Ще $з$ радянських часів інститут екстрадиції досліджувався такими відомими вченими-міжнародниками, як: А. Абашидзе, Р. Валеєв, В. Грабарь, Л. Галенська, Е. Коровін, І. Лукашук, А. Наумов, Н. Сафаров, ін. Підвищений інтерес до дослідження процедури екстрадиції останнім часом спостерігається серед вітчизняних учених. Як видається, це пов'язано насамперед із його «затребуваністю» (зокрема, існувало й існує чимало проблем із видачею П. Лазаренка, Б. Данилишена, В. Каськіва, О. Клименка, В. Януковича, А. Портнова, В. Пшонки, В. Захарченка, О. Онищенко й ін.). Серед вітчизняних дослідників варто виділити праці О. Бандурки, О. Буткевич, В. Березняка, О. Виноградової, С. Вихриста, О. Зелінської, І. Кушніра, С. Лихова, С. Нестеренко, М. Свистуленко й ін. 
Водночас варто зазначити, що, незважаючи на таку велику кількість праць, усе ж комплексних досліджень, які б ураховували багатогранність та складну природу екстрадиції, а також новітні тенденції міжнародного кримінального права, в Україні немає.

\section{1. Загальні засади співробітництва та взаємодії держав у сфері екстрадиційних процесів}

Процедура екстрадиції на практиці, особливо коли йдеться про видачу високопосадовців, є надзвичайно складною і проблематичною. Ще більш складною, як показує практика, $\epsilon$ видача осіб міжнародним судовим установам, коли йдеться про вчинення особливої категорії злочинів «міжнародних злочинів»: геноциду, агресії, військових злочинів чи злочинів проти людяності. Безперечно, у таких випадках $\epsilon$ необхідність у налагодженні чіткого механізму співпраці між державами із цих питань, а також між державами та міжнародними органами кримінальної юстиції.

Перший момент, на який варто звертати увагу, коли йдеться про співробітництво держав із міжнародними судовими установами, - це питання процедури створення такої установи. Наприклад, перші міжнародні військові трибунали - Нюрнберзький та Токійський - були засновані на підставі відповідних угод: Нюрнберзький - відповідно до рішень Потсдамської конференції (17 липня - 2 серпня 1945 р.) глав союзницьких держав Союзу Радянських Соціалістичних Республік (далі СРСР), Сполучених Штатів Америки (далі - США) і Великобританії про покарання воєнних злочинців Другої світової війни 1939-1945 pp., у Лондоні між урядами СРСР, США, Великобританії та Франції у 1945 р. відбулося укладення угоди про створення Міжнародного воєнного трибуналу для переслідування та покарання головних воєнних злочинців європейських країн, а Токійський - заснований Угодою 1946 р. за участю СРСР, США, Великобританії, Китаю, Франції, Австралії, Канади, Нової Зеландії, Нідерландів, Індії та Філіппін. Натомість міжнародні кримінальні трибунали щодо колишньої Югославії (далі - МКТЮ) та Руанди (далі МКТР) були засновані резолюціями Ради безпеки Організації Об'єднаних Націй (далі -OOH) на підставі гл. VII Статуту ООН (щодо Югославії в 1993 р., по Руанді - у 1994 р.). Відповідно держави-учасниці ООН зобов'язані співпрацювати із цими трибуналами. Це означає надання допомоги та сприяння держав на всіх стадіях провадження у справі (збір доказів, опитування свідків, підозрюваних, експертів, встановлення місцезнаходження осіб, вручення документів тощо). Крім цього, рішення щодо ордерів на арешт, обшук, передачу або переведення осіб та інші теж підлягають виконанню державами. Міжнародний кримінальний суд, у 
свою чергу, створено на підставі договору між державами (Римський статут). Якщо держава не уклала і не ратифікувала цей договір, вона не зобов'язана виконувати вказівки цього Суду щодо надання правової допомоги та передачі осіб. Тобто цей момент є надзвичайно важливим.

Другий момент, не менш важливий, пов'язаний із тим, що без співпраці держав із міжнародними судовими установами їхня діяльність фактично блокується. Адже такі міжнародні суди не наділені такими повноваженнями, як розшук, арешт обвинувачених на територіях держав, їх видача тощо, як це відбувається в рамках національних правових систем, де правоохоронні органи мають широке коло таких повноважень. Тому співпраця 3 національними властями для міжнародних судових установ $є$ необхідністю, без відповідної допомоги їхне ефективне функціонування, як слушно підкреслює відомий юрист-міжнародник А. Кассезе, було б неможливим.

Крім наведеного, також слушне застереження I. Марусина, який звертає увагу на те, що дії як у процесі попереднього розслідування, так і під час безпосереднього розгляду справи, відбуваються на території тієї чи іншої держави, отже, підпадають під іiі юрисдикцію. А тому на їх здійснення органи міжнародної юстиції мають отримати згоду цієї держави ${ }^{1}$.

Отже, з огляду на наведені особливості стає зрозумілим, що концепція співпраці держав із міжнародними судовими установами суттєво відрізняється від концепції надання правової допомоги у кримінальних справах між державами. Співпраця держав здійснюється на основі так званої «горизонтальної моделі», тоді як співпраця держав із міжнародними трибуналами - на основі «вертикальної моделі»².

\section{2. «Горизонтальна» $\mathbf{i}$ «вертикальна» моделі співпраці \\ та взасмодії держав у сфері кримінального правосуддя}

Сутність «горизонтальної моделі» полягає в такому: співробітництво та взаємодія між державами як основними акторами міжнародних відносин та рівноправними суб'єктами міжнародного права грунтуються на принципі суверенної рівності держав. Така імперативна норма закріплена у ст. 2 Статуту $\mathrm{OOH}^{3}$ і сприймається як норма jus cogens, відступ від якої заборонено в міжнародному праві. Без дозволу держави на ii території неможливо проводити жодних процесуальних дій (обшук, допит, арешт,

\footnotetext{
1 Марусин И. Международные уголовные судебные учреждения : Судоустройство и судопроизводство : монография. Санкт-Петербург : Издат. дом С.-Петерб. гос. ун-та, 2004. С. 146.

2 Сафаров Н. Сотрудничество в области уголовного правосудия: «горизонтальная» и «вертикальная» модели. Международное уголовное правосудие: современные проблемы / под ред. Г. Богуша, Е. Трикоз. Москва : Институт права и публичной политики, 2009. С. 429.

3 Устав Организации Объединённых Наций и Устав Международного Суда 1945 г. URL: http://zakon3.rada.gov.ua/laws/show/995_010.
} 
розшук тощо). Крім цього, важливе дотримання принципу належного виконання взятих на себе міжнародних зобов'язань, який означає, що в разі укладення відповідної угоди про надання правової допомоги у кримінальних справах держава бере на себе зобов'язання, які має виконувати.

Щодо природи та сутності «вертикальної моделі», потрібно враховувати те, що така модель застосовується в разі взаємодії держав із міжнародними кримінальними трибуналам ad hoc, статути яких передбачають відповідні зобов'язання держав щодо надання допомоги трибуналам у кримінальних справах щодо осіб, які звинувачуються у вчиненні міжнародних злочинів, які посягають на мир та безпеку у світі. У цьому разы юрисдикція трибуналів превалювала над юрисдикцією національних судів. Однак така модель не може бути сприйнята, коли йдеться про МКС, який не має переваг над національними судами, оскільки функціонує на підставі принципу компліментарності. Ця норма випливає з того факту, що Статут набув форми договору, на який поширюють процедуру добровільного визнання. Як наслідок - МКС, заснований на підставі договору, може ухвалювати рішення, які будуть мати чинність тільки щодо державучасниць.

Згідно зі ст. 17 Римського статуту МКС ${ }^{4}$, Суд може прийняти справу до свого провадження тоді, коли держава не бажає або неспроможна проводити розслідування чи порушити кримінальне переслідування належним чином. Юрисдикція МКС поширюється на злочини, учинені на території держави-учасниці або громадянином відповідної держави.

Під час співпраці міжнародних судових установ та держав щодо надання останніми допомоги у кримінальних справах виникає чимало проблем.

Передусім у численних міжнародних договорах між державами про надання допомоги у кримінальних справах чітко прописуються підстави для відмови у співпраці, зокрема й передачі осіб. У цьому плані ООН свого часу Резолюцією Генеральної асамблеї затвердила Типовий договір про взаємну допомогу у сфері кримінального правосуддя (14 грудня 1990 р. $)^{5}$, у якому передбачено положення про те, що за посилання на державний суверенітет запитувана держава може відмовити у взаємодії (ст. 4). Наприкладу це може стосуватися категорії політичних злочинів. Тому звернення МКС може бути проігноровано. Однак якщо таке звернення направлене міжнародними трибуналами, то, однозначно, сторона не має права відхилити його. У таких випадках мотивація про те, що діяння може

\footnotetext{
${ }^{4}$ Римский статут Международного уголовного суда от 17 июля 1998 г. URL: http://zakon2.rada.gov.ua/ laws/show/995_588.

5 Типовой договор о взаимной помощи в области уголовного правосудия. Резолюция 45/117 Генеральной Ассамблеи от 14 декабря 1990 г. URL: http://zakon2.rada.gov.ua/laws/show/995_833.
} 
бути кваліфіковано як політичний злочин, не приймається. Статути трибуналів узагалі не передбачають підстав для відмови. Діяння, які підпадають під юрисдикцію трибуналів, - військові злочини та злочини проти людяності, не можуть відноситись до категорії політичних злочинів. Така деполітизація прямо передбачається в низціі міжнародних конвенцій. Зокрема, такі положення містить Конвенція про запобігання злочину геноциду та покарання за нього, Додатковий протокол до Європейської конвенції про екстрадицію. Міжнародна судова практика йде шляхом невизнання винятків стосовно політичних злочинів із категорії військових злочинів та злочинів проти людяності, оскільки у протилежному випадку можна було б вести мову про уникнення від відповідальності за вчинення міжнародних злочинів, які посягають на мир та безпеку у світі, а це можна розглядати як порушення імперативних норм міжнародного права (jus cogens). Таку позицію було представлено у справі Prosecutor v. Anto Furundzija, яка розглядалась МКТЮ ${ }^{6}$. Отже, наведене дає підстави стверджувати, що питання характеру злочинного діяння взагалі не може бути предметом розгляду, коли направляється прохання від міжнародних трибуналів ad hoc.

Водночас у Типовому договорі (ст. 4) передбачено шість підстав для відмови у співпраці, коли йдеться про взаємодію між державами в наданні правової допомоги у кримінальних справах: (1) виконання прохання може зашкодити державним інтересам: суверенітету, безпеці, громадському порядку тощо; (2) діяння може розглядатись як політичний злочин; (3) коли $є$ підозра в тому, що прохання направлене 3 метою судового переслідування за дискримінаційними ознаками (раси, кольору, статі, віросповідання, етнічної приналежності й інше); (4) прохання стосується правопорушення, яке $\epsilon$ предметом судового розгляду в запитуваній державі, що несумісне із принципом "non bis in idem" (особа не може нести відповідальність за те ж саме діяння двічі); (5) прохання стосується застосування примусових заходів, які суперечать національному законодавству в разі розгляду справи на території даної держави; (6) прохання стосується правопорушення щодо військового права, але водночас воно не $\epsilon$ таким за загальним кримінальним правом ${ }^{7}$.

Крім цього, передбачено можливість додаткових підстав. Однак ці підстави не застосовуються або ж можуть бути зведені до мінімуму в разі звернень міжнародних трибуналів ad hoc.

\footnotetext{
6 Прокурор против Антонио Фурунца. 10 декабря 1998 г. Дело № IT-95-7/1-A. URL: http://www.icty.org/x/cases/furundzija/tjug/en/fur-tj981210e.pdf.

7 Типовой договор о взаимной помощи в области уголовного правосудия. Резолюция 45/117 Генеральной Ассамблеи от 14 декабря 1990 г. URL: http://zakon2.rada.gov.ua/laws/show/995_833.
} 
Досить серйозною підставою щодо відмови надання допомоги у практиці «горизонтальної моделі» уважається підстава щодо «подвійного зобов'язання». Типовий договір надає державам таку можливість передбачити у відповідних двосторонніх та багатосторонніх договорах про допомогу. Досить багато держав, серед яких США, Швеція, Угорщина, Болгарія, Литва, передбачили у відповідних договорах положення про відмову в наданні допомоги, якщо запит стосується діяння, яке за національним законодавством не $\epsilon$ кримінально караним ${ }^{8}$. Наприклад, таку підставу передбачено в Конвенції проти організованої транснаціональної

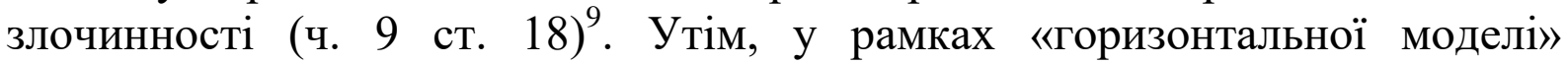
прохання трибуналів не може бути відхилено за такою підставою. Тобто «горизонтальне» співробітництво враховує інтереси держав, у разі «вертикального» - міжнародного співтовариства (адже йдеться про притягнення до відповідальності за вчинення міжнародних злочинів агресії, геноциду, військових злочинів, злочинів проти людяності), а тому часто винятки з останньої моделі не враховуються.

Статути міжнародних судових установ теж містять положення, які засвідчують окремі виняткові випадки під час співпраці. Так, у ч. 4 ст. 93 Статуту МКС передбачено, що держава-учасниця може відмовити у проханні про допомогу, повністю або частково, лише в тому разі, якщо запит стосується пред’явлення будь-яких документів або розкриття доказів, які стосуються її національної безпеки ${ }^{10}$.

Під час порівняння «горизонтальної» та «вертикальної» моделей можна також стверджувати, що останнім часом у рамках першої склалась тенденція щодо відмови у виконанні запитів стосовно співпраці у випадках, коли є всі підстави вважати, що таке виконання буде причиною порушення прав людини. Інколи навіть положення національного кримінального законодавства закріплюють тезу про те, що запит може бути виконано щодо надання допомоги, якщо водночас не буде порушено положень Європейської конвенції про захист основних прав і свобод людини 1950 p. $^{11}$ (зокрема, ст. 6 португальського Закону про міжнародну правову допомогу у кримінальних справах). У разі «вертикальної»

\footnotetext{
${ }^{8}$ Милинчук В. Институт взаимной правовой помощи по уголовным делам. Москва: Юрлитинформ, 2001. С. 67.

9 Конвенція Організації Об’єднаних Націй проти транснаціональної організованої злочинності, ухвалена резолюцією 55/25 Генеральної Асамблеї від 15 листопада 2000 p. URL: http://zakon2.rada.gov.ua/ laws/show/995_789.

${ }^{10}$ Римский статут Международного уголовного суда от 17 июля 1998 г. URL: http://zakon2.rada.gov.ua/ laws/show/995_588.

${ }^{11}$ Конвенція про захист прав людини і основоположних свобод 1950 p. URL: http://zakon5.rada.gov.ua/ laws/show/995_004.
} 
співпраці такі винятки не беруться до уваги, оскільки високі міжнародні стандарти відправлення правосуддя в міжнародних трибуналах виключають можливість порушення прав людини. Тому прийнято вважати, що такі побоювання не $є$ виправданими.

Також під час порівняння різних моделей співпраці щодо надання допомоги у кримінальних справах має значення використовувана термінологія. Якщо «горизонтальна модель» припускає вживання терміна «взаємна допомога», то у «вертикальній» - «співпраця у кримінальних справах» або «міжнародне співробітництво та судова допомога». Так, про взаємну допомогу згадують Європейська конвенція про взаємну допомогу у кримінальних справах ${ }^{12}$, Типовий договір $\mathrm{OOH}$ про взаємну правову допомогу в галузі кримінального правосуддя, про співпрацю у кримінальних справах, ст. 29 Статуту МКТЮ, ст. 28 Статуту МКТР, а про міжнародне співробітництво та судову допомогу йдеться в розд. 9 Статуту МКС.

Отже, можна стверджувати, що заснування та функціонування на міжнародній арені низки міжнародних судових установ, наділених компетенцією щодо переслідування індивідів, які підозрюються у вчиненні міжнародних злочинів (геноцид, агресія, військові злочини, злочини проти людяності), привело до виникнення нових, раніше не відомих міжнародній практиці юридичних процедур співпраці, які суттєво відрізняються від традиційної моделі «горизонтальної» співпраці між державами щодо надання допомоги у кримінальних справах, зокрема і стосовно видачі осіб.

\section{3. Особливості екстрадиції та передачі осіб у рамках міжнародних кримінальних трибуналів і судів}

Як демонструє сучасна практика співробітництва держав у сфері надання правової допомоги у кримінальних справах, одне із центральних місць у цьому посідає процедура видачі осіб. Аналогічна ситуація і в разі, коли йдеться про видачу осіб міжнародним судовим установам. Практично без цієї процедури міжнародне правосуддя втрачає сенс, оскільки особи, які вчиняли б міжнародні злочини, мали б змогу ховатися в «лояльній» до них країні й уникати покарання. Однак така видача осіб, безумовно, 3 огляду на специфіку міжнародної кримінальної юстиції, має відбуватися теж у рамках особливих процедур, які відмінні від тих, що традиційно $\epsilon$ усталеними за «горизонтальної» взаємної допомоги держав. Особливо активізувались ці питання після заснування МКС, який притягує до відповідальності індивідів за вчинення міжнародних злочинів.

\footnotetext{
${ }^{12}$ Свропейська конвенція про взаємну допомогу у кримінальних справах. Страсбург, 20 квітня 1959 р. URL: http://zakon3.rada.gov.ua/laws/show/995_036.
} 
Процедура передачі осіб передбачена як Римським статутом МКС, так і Статутами міжнародних трибуналів щодо колишньої Югославії та Руанди. Крім того, Правила процедури і доказування цих трибуналів містять положення про те, що зобов'язання відповідно до ст. ст. 29 і 28 Статутів МКТЮ i МКТР мають пріоритет над іншими, які передбачені в національному законодавстві про екстрадицію чи міжнародними договорами про правову допомогу, укладеними відповідною державою. Таке положення випливало із пріоритету юрисдикції трибуналів щодо юрисдикції національних судів. Навіть більше, на будь-якій стадії судового розгляду в національному суді трибунали мали право вимагати передати їм цю справу. Так відбулось у відомій справі Душко Тадіча ${ }^{13}$, яка спочатку розглядалась із 1994 р. мюнхенським судом, але згодом МКТЮ витребував цю справу, мотивував це тим, що вона становить особливу важливість для судового переслідування осіб, відповідальних за серйозні порушення міжнародного гуманітарного права. Примітно, що для передачі такої справи не потрібне укладання спеціальної угоди із трибуналами. Відсутність іï не є підставою для відмови в передачі справи для розгляду трибуналом. Хоча таку угоду держава може й укласти. Практика дає відповідні приклади.

Так, руандійський громадянин Елізафан Нтакірутіман (етнічний хунту), який звинувачувався МКТР у вчиненні злочинів проти людяності та геноциді, був заарештований у штаті Техас (м. Ларедо). Трибунал звернувся до США щодо передачі даної особи. США уклали із МКТР спеціальну виконавчу угоду про передачу. До США приєднались інші країни: Австрія, Бельгія, Німеччина, Швейцарія, Франція. Ці країни у своєму внутрішньонаціональному кримінальному законодавстві передбачили відповідні положення про екстрадицію на підставі угоди із трибуналом ${ }^{14}$.

Примітно, якщо в національному законодавстві багатьох закордонних країн фігурує термін «екстрадиція», то у статутах міжнародних судових установ замість нього вживаються терміни «передача» або «переведення» (наприклад, Статути трибуналів щодо колишньої Югославії та Руанди). Водночас вони чітко не розмежовані.

Однак окремі науковці схильні розмежовувати ці поняття. Так, на думку В. Морріса та М. Шрафа, «передача» має місце, коли особа витребувана трибуналом, уже звинувачена національним судом і перебуває під вартою на теренах запитуваної держави, а в разі «переведення» особа

13 Лауччи С. Преследовать в судебном порядке и обеспечить судебное преследование лиц, совершивших серьезные нарушения международного гуманитарного права. URL: https://www.icrc.org/ rus/assets/files/other/ 04_irrc_842_laucci_rus.pdf.

${ }^{14}$ Сафаров Н. Экстрадиция в международном уголовном праве: проблемы теории и практики. Москва : Волтерс Клувер, 2005. С. 302-303. 
заарештовується згідно з наказом трибуналу і передається для подальшого розгляду справи цьому трибуналу. На нашу думку, така позиція не підтверджується ні положеннями статутів трибуналів, ні міжнародною практикою. Тому між цими термінами, як видається, немає розходжень.

У тексті Римського статуту, як і у Статутах трибуналів щодо колишньої Югославії та Руанди, уживається термін «передача осіб» (ст. ст. 89, 90, 91, $101,102)$. Серед основних положень щодо передачі осіб варто зазанчити такі: суд може направити прохання про арешт і передачу особи разом із відповідними матеріалами, зазначеними у ст. 91 Римського статуту, будьякій державі, на території якої може перебувати ця особа, і звернутися до цієї держави із проханням про співробітництво в іiї арешті, передачі такої особи. Держави-учасниці відповідно до положень цієї частини i процедури, передбаченої їхнім національним законодавством, виконують прохання про арешт та передачу.

Зазначимо, що до позитивних моментів регламентації процедури передачі особи Римським статутом МКС варто віднести те, що, на відміну від Статутів трибуналів по колишній Югославії та Руанді, у ньому проводиться розмежування понять «екстрадиція» (ужито в багатьох національних законах про надання правової допомоги у кримінальних справах) та «передача» (ужито у статутах міжнародних судових установ). Ст. 102 передбачає: «екстрадиція» - доставка особи однією державою в іншу згідно з положеннями міжнародного договору, конвенції чи актів національного законодавства; «передача» - доставка особи державою до Суду відповідно до Статуту. Таке положення, яке роз'яснює вживані терміни, має надзвичайно велике значення для практики видачі осіб трибуналам.

Крім проблем щодо різного сприйняття термінології, у практиці міжнародного співробітництва в питаннях видачі осіб міжнародним трибуналам та судам виникає чимало й інших. Найбільш гострою проблемою є видача власних громадян.

Аналіз екстрадиційної практики закордонних держав із досліджуваної проблеми засвідчує, що нині склались два підходи до цього питання: (1) абсолютна заборона видачі власних громадян; (2) відносна заборона 3 деякими винятками (якщо держави уклали відповідний договір, у якому передбачено видачу на умовах взаємності). Перший підхід має надзвичайно багато прихильників. Серед учених найбільш активно підтримують таку позицію відомі західні юристи: К. Біндінг, Г. Майєр, С. Пуфендорф. На їхню думку, заборона видачі випливає зі стану громадянства, який проявляється у двосторонньому правовому зв'язку особи та держави: $з$ одного боку - громадянин має дотримуватись законів 
держави свого громадянства, 3 іншого - держава зобов'язана надавати захист і гарантувати права своїм громадянам. У разі видачі немає гарантій того, що права громадянина не будуть порушені, є ймовірність того, що держава за таких обставин може прямо порушувати свої зобов'язання стосовно громадянина, позбавляє його гарантій у здійсненні правосуддя, що передбачені в їі законодавстві. Крім цього, прибічники заборони видачі також акцентують увагу на тому, що всі держави на міжнародній арені передусім зважають на національні інтереси, вони не повинні дотримуватися інтересів інших держав і піклуватися про підтримку порядку в іншій державі. Тобто основний аргумент можна звести до такого: заборона видачі випливає, по-перше, із взаємної відповідальності особи та держави, по-друге, iз принципу поваги державного суверенітету ${ }^{15}$.

Натомість прихильники другого підходу, серд яких Г. Гроцій, Ф. Мартенс, Д. Нікольський, Е. Сімсон, виправдовували видачу власних громадян у виняткових випадках, висували такі аргументи: а) за злочин особа має нести відповідальність незалежно від громадянства; б) якщо злочин вчинено на території іноземної держави, то і розслідування буде ефективнішим саме на території цієї держави (допити свідків, зібрання доказів тощо); в) держава не завжди може бути справедливою в захисті інтересів іноземної держави і не має таких зобов'язань у принципі, якщо буде карати власного громадянина за злочин, який увчинено на території іншої держави і стосується порушення їі інтересів ${ }^{16}$.

У більшості конституцій закордонних країн містяться положення саме про заборону видачі власних громадян. Виходячи зі змісту таких положень, постають запитання, чи можлива така видача в разі звернень міжнародних судових установ, чим така видача повинна мотивуватись?

За межі конституційних вимог, безумовно, виходити не можна. Потрібно вносити відповідні зміни до Основного закону країни ${ }^{17}$. Водночас аналіз конституційних положень засвідчує, що ці заборони стосуються видачі власних громадян іноземній державі, ідеться саме про взаємодію та співробітництво держав (часто таке твердження є дискусійним і піддається критиці). Які аргументи можна навести на підтвердження такої позицій?

По-перше, міжнародна кримінальна юстиція - відносно нове явище в міжнародному праві. Ї̈ї поява пов'язана зі створеннями перших міжнародних військових трибуналів - Нюрнберзького та Токійського після Другої світової війни. Натомість, як відомо, більшість конституцій

\footnotetext{
15 Овсійчук Т. Заборона видачі власних громадян як підстава відмови у здійсненні екстрадиції. URL: http://er.nau.edu.ua:8080/bitstream/NAU.PDF.

16 там само.

17 Сафаров Н. Проблемы толкования Римского статута Международного уголовного суда (опыт органов конституционной юстиции). АРЖМСП. 2004. № 1. С. 4-38.
} 
закордонних країн ухвалювалися в період між двома світовими війнами, а тому, природно, передбачити положення про екстрадицію осіб міжнародним трибуналам не могли. Зважаючи на те, що МКС не $\epsilon$ «іноземним судом» або ж це не «іноземна юрисдикція», конституційні заборони проти екстрадиції громадян не можуть застосовуватися.

По-друге, зважаючи на те, що після Другої світової війни більшість конституцій передбачили положення про примат норм міжнародного права в галузі захисту основоположних прав людини, пріоритет основних принципів міжнародного права (норми jus cogens, а саме: заборона застосування сили в міжнародних відносинах, мирне вирішення спорів, дотримання міжнародних зобов'язань, захист прав людини тощо), а також положення про те, що людина $є$ найбільшою соціальною цінністю, видача міжнародним судовим установам осіб, які підозрюються у вчиненні міжнародних злочинів, які посягають на міжнародний правопорядок, мир та безпеку людства, а зрештою на права та свободи людини, є природним відображенням людиноцентристських тенденцій у сучасному світі. Навіть якщо в конституціях закордонних країн немає положень про передачу чи видачу осіб міжнародним трибуналам чи судам, це імпліцитно можна вивести зі змісту наведених положень.

Проте часто такі аргументи піддаються критиці. Опоненти такої позиції вважають, що кожна суверенна держава має право, а не обов'язок, визначати, яку особу видавати, а яку ні, якщо тільки вона не має укладених міжнародних угод щодо цього. Однак часто таких угод немає. Це пов'язано не тільки з небажанням держав зв'язувати себе зобов'язаннями, а й із тим, що розвиток галузі міжнародного кримінального права й інституту міжнародної кримінальної юстиції не можна вважати стрімким. Як відомо, у міжнародному праві - особливі суб'єкти (ідеться передусім про головних акторів міжнародних відносин) - держави, які володіють рівними права (принцип суверенної рівності держав). Процес ухвалення норм міжнародного кримінального права довготривалий (потрібно узгодити волі багатьох суб'єктів, які не тільки встановлюють певне правило, а й дають згоду добровільно його виконувати). Навіть більше, жоден міжнародний договір не $\epsilon$ чинним для держави, якщо вона належним чином не імплементувала його. Наприклад, Україна підписала Римський статут МКС, однак Верховна Рада України не ратифікувала його шляхом ухвалення відповідного закону про ратифікацію, тобто для нашої держави Римський статут так і не набрав чинності. Безперечно, усі ці обставини негативно відображаються на процесі реалізації норм інституту видачі осіб. Зокрема, питання про передачу осіб МКС було відкритим до самого ухвалення Римського статуту МКС. 
Загалом варто зазанчити, що в окремих країнах практично, де потрібно було вносити зміни до Конституції у зв'язку з підписанням Римського статуту МКС, у якому передбачені положення про зобов'язання запитуваної держави передати ту чи іншу особу МКС, юристи використали т. зв. інтерпретаційний підхід, пов'язаний із тлумаченням відповідних конституційних положень. Зокрема, така практика відома Швейцарії, ст. 25 (1) Основного закону якої ${ }^{18}$ передбачає заборону екстрадиції власних громадян, водночас підкреслюється, що для видачі власних громадян потрібна їхня згода. Після підписання Римського статуту МКС постало питання про внесення змін до Конституції. Федеральна рада Швейцарії (уряд) 15 листопада 2000 р. у своєму посланні розтлумачила, що ст. 25 (1) Конституції в разі передачі особи МКС не підлягає застосуванню, оскільки в самому Статуті МКС дано розмежування процедур екстрадиції та передачі (ст. 102): «екстрадиція» стосується передавання особи однією державою іншій, а «передача» означає видачу особи МКС ${ }^{19}$.

Примітно, що Конституційний Суд України (далі - КСУ) теж провів розмежування термінів «екстрадиція» та «передача» у своєму висновку у справі про відповідність Конституції України Римському статуту МКС ${ }^{20}$. КСУ звернув увагу на те, що часто в разі загального вживання даних термінів вони застосовуються як синоніми, однак аналіз міжнародноправових документів засвідчує, що в міжнародних відносинах «видача» (або «екстрадиція») і «передача» - не ідентичні. Якщо перше стосується співробітництва держав та видачі осіб однією державою іншій, то у другому випадку йдеться про видачу особи МКС. Тому заборона видачі (екстрадиції) громадян України, що міститься у ст. 25 Конституції України ${ }^{21}$, стосується лише національної, а не міжнародної юрисдикції. Крім цього, у висновку йдеться і про те, що з огляду на принцип компліментарності, який передбачений Статутом МКС, у разі задіяння механізму внутрішньонаціональної юрисдикції щодо осіб, які винні у вчиненні міжнародних злочинів, МКС не буде здійснювати щодо таких осіб власної юрисдикції, а тому можливість їх передачі в такому разі виключається. 3 огляду на наведені положення висновку КСУ стає

\footnotetext{
18 Союзная конституция Швейцарской Конфедерации от 18 апреля 1999 г. URL: http://www.concourt.am/armenian/legal_resources/world_constitutions/ constit/swiss/swiss--r.htm.

19 Римський статут міжнародного кримінального суду. URL: http://zakon3.rada.gov.ua/laws/ show/995_588.

20 Висновок Конституційного Суду України у справі за конституційним поданням Президента України про надання висновку щодо відповідності Конституції України Римського статуту Міжнародного кримінального суду (справа про Римський статут), 11 липня 2001 р. Справа № 1-35/2001 № 3-в/2001. URL: http://zakon5.rada.gov.ua/laws/show/v003v710-01.

${ }^{21}$ Конституція України від 28 червня 1996 р. 3 наступними змінами. URL: http://zakon3.rada.gov.ua.
} 
зрозумілим, що КСУ, як і Федеральна рада Швейцарії, використав т. зв. інтерпретаційний підхід.

Загалом під час дослідження питань екстрадиції та передачі осіб міжнародним кримінальним трибуналам і судам варто зважати на такі моменти: (1) екстрадиція у традиційному розумінні являє собою міждержавний правовий інститут, змістом якого є доставка за запитом іноземної держави особи для кримінального переслідування або виконання покарання, а тому iї найважливіша характеристика - міждержавний характер, а передача являє собою інститут видачі особи міжнародним судовим установам; (2) відносини екстрадиції та передачі розрізняються за підставами виникнення, складом суб'єктів, цілями, наслідками. Вирішальним аргументом на користь розмежування розглянутих процедур $€$ відмінності в суб'єктах співпраці. Якщо в разі екстрадиції це дві держави, то в разі передачі осіб це, з одного боку, міжнародна судова установа (наприклад, МКС), а з іншого - держава, якій адресується вимога про передачу. Під час передачі осіб міжнародним судовим установам діє різний механізм. У разі видачі осіб міжнародним кримінальним трибуналам щодо колишньої Югославії та Руанди держави мають обов'язок передати дану особу, у разі направлення такого запиту МКС має значення участь держави в Римському статуті МКС; (3) процедура передачі особи чи осіб МКС має свої особливості: а) екстрадиція, на відміну від передачі, передбачає можливість отримання державою як обвинуваченого для здійснення кримінального переслідування, так i засудженого для виконання раніше винесеного вироку, а в разі передачі йдеться про обвинуваченого, який повинен постати перед МКС; б) зазвичай засуджена органами національної кримінальної юстиції особа не може бути передана МКС (ч. 1 ст. 20) за окремими винятками (особа, яка була засуджена національними судовими органами за злочин, що підпадає під юрисдикцію МКС, може бути повторно засуджена, коли: 1) розгляд призначався для того, щоб захистити відповідну особу від кримінальної відповідальності за злочини, що підпадають під юрисдикцію Суду; 2) розгляд не було проведено незалежно або неупереджено відповідно до норм належної законної процедури, визнаних міжнародним правом, і проводився таким чином, що за існуючих обставин не відповідав основній меті правосуддя - справедливому понесенню покарання за вчинене злочинне діяння); (4) у разі екстрадиції потенційна можливість порушення прав людини дозволяє відхилити запит про видачу, у разі передачі такий підхід взагалі виключається (система розслідування та розгляду в міжнародних судових установах грунтується на міжнародних стандартах прав людини, до участі в розслідуванні та розгляді справи 
залучені висококваліфіковані незалежні фахівці з багатим практичним досвідом із різних закордонних країн); (5) принцип «подвійного зобов'язання» у практиці міжнародних судових установ не застосовується. Це означає, що держава не може відмовити в передачі особи на тій підставі, що прохання стосується злочину, який не криміналізований у національному кримінальному законодавстві. Однак потрібно враховувати i те, що нині практично всі держави передбачають у національному кримінальному законодавстві міжнародні злочини як найбільш небезпечні, отже, ці діяння переслідуються та караються з боку держави.

Отже, з огляду на наведене можна констатувати, що передача осіб $\epsilon$ самостійною юридичною процедурою, яка реалізується у відносинах держав із міжнародними судовими установами, на яку не поширюється жодне $з$ екстрадиційних обмежень, які застосовуються в міждержавній практиці, зокрема й невидача власних громадян.

\section{ВИСНОВКИ}

Аналіз проблемних питань екстрадиції та передачі осіб міжнародним судовим установам дозволяє зробити висновок про те, що в сучасних міжнародних відносинах взаємодія держав у наданні правової допомоги у кримінальних справах $\epsilon$ необхідним елементом міжнародного співробітництва. Ураховуючи сучасні тенденції щодо розвитку міжнародної кримінальної юстиції та міжнародного кримінального права, можна зазначити, що екстрадиційні відносини дедалі ускладнюються, поряд із традиційними процедурами екстрадиції починають застосуватись нові, зокрема передача осіб міжнародним судовим установам. Це зумовило появу двох різних моделей - «горизонтальної» та «вертикальної», які суттєво відрізняються одна від одної. Якщо для першої моделі характерна взаємодія держав у питаннях видачі осіб на умовах укладених ними спеціальних договорів та угод про надання правової допомоги у кримінальних справах, то у другій ідеться про співпрацю держав із міжнародними судовими установами без наявності таких угод (за винятком МКС, оскільки в даному разі має значення те, підписала й імплементувала Римський статут держава чи ні).

\section{АНОТАЦІЯ}

Підрозділ присвячений дослідженню та розмежуванню таких понять, як «екстрадиція» і «передача осіб», коли йдеться про міжнародне кримінальне переслідування. Автори доходять висновку, що «екстрадиція» являє собою доставку особи однією державою в іншу згідно 3 положеннями міжнародного договору, конвенції чи актів національного законодавства; 
«передача», у свою чергу, означає доставку особи державою до міжнародного кримінального судового органу. 3 урахуванням цього встановлено наявність двох концепцій співпраці: горизонтальної співпраця держав у питаннях надання правової допомоги у кримінальних справах, вертикальної - співробітництво держав із міжнародними судовими установами, які суттєво відрізняються одна від одної. Особливість підрозділу полягає також у проведенні аналізу міжнародних, внутрішньодержавних нормативно-правових актів та різних доктринальних позиції, зі змісту яких автори доходять висновку, що, окрім проблем різного сприйняття термінології, у практиці міжнародної співпраці в питаннях видачі осіб міжнародним трибуналам і судам виникає чимало й інших. Найбільш гострою проблемою є видача власних громадян.

\section{ЛІТЕРАТУРА}

1. Висновок Конституційного Суду України у справі за конституційним поданням Президента України про надання висновку щодо відповідності Конституції України Римського статуту Міжнародного кримінального суду (справа про Римський статут), 11 липня 2001 р. Справа № 1-35/2001 № 3-в/2001. URL: http://zakon5.rada.gov.ua/laws/show/v003v710-01 .

2. Європейська конвенція про взаємну допомогу у кримінальних справах. Страсбург, 20 квітня 1959 p. URL: http://zakon3.rada.gov.ua/laws/ show/ 995_036.

3. Конвенція Організації Об'єднаних Націй проти транснаціональної організованої злочинності, ухвалена резолюцією 55/25 Генеральної Асамблеї від 15 листопада 2000 p. URL: http://zakon2.rada.gov.ua/laws/ show/995_789.

4. Конвенція про захист прав людини і основоположних свобод 1950 р. URL: http://zakon5.rada.gov.ua/laws/show/995_004.

5. Конституція України від 28 червня 1996 р. $з$ наступними змінами. URL: http://zakon3.rada.gov.ua.

6. Лауччи С. Преследовать в судебном порядке и обеспечить судебное преследование лиц, совершивших серьезные нарушения международного гуманитарного права. URL: https://www.icrc.org/rus/assets/files/other/ 04_irrc_842_laucci_rus.pdf.

7. Марусин И. Международные уголовные судебные учреждения : Судоустройство и судопроизводство : монография. Санкт-Петербург : Издат. дом С.-Петерб. гос. ун-та, 2004. С. 146.

8. Милинчук В. Институт взаимной правовой помощи по уголовным делам. Москва : Юрлитинформ, 2001. 352 с. 
9. Овсійчук Т. Заборона видачі власних громадян як підстава відмови у здійсненні екстрадиції. URL: http://er.nau.edu.ua:8080/bitstream/NAU.PDF.

10. Прокурор против Антонио Фурунца. 10 декабря 1998. Дело № IT-95-7/1-A. URL: http://www.icty.org/x/cases/furundzija/tjug/en/furtj981210e.pdf.

11. Римский статут Международного уголовного суда от 17 июля 1998 г. URL: http://zakon2.rada.gov.ua/laws/show/995_588.

12. Сафаров Н. Сотрудничество в области уголовного правосудия: «горизонтальная» и «вертикальная» модели. Международное уголовное правосудие: современные проблемы / под ред. Г. Богуша, Е. Трикоз. Москва : Институт права и публичной политики, 2009. С. 429-443.

13. Сафаров Н. Проблемы толкования Римского статута Международного уголовного суда (опыт органов конституционной юстиции). АРЖМСП. 2004. № 1. С. 4-38.

14. Сафаров Н. Экстрадиция в международном уголовном праве : проблемы теории и практики. Москва : Волтерс Клувер, 2005. 416 с.

15. Союзная конституция Швейцарской Конфедерации от 18 апреля 1999 г. URL: http://www.concourt.am/armenian/legal_resources/world_ constitutions/ constit/swiss/swiss--r.htm.

16. Типовой договор о взаимной помощи в области уголовного правосудия. Резолюция 45/117 Генеральной Ассамблеи от 14 декабря 1990 г. URL: http://zakon2.rada.gov.ua/laws/show/995_833.

17. Устав Организации Объединённых Наций и Устав Международного Суда 1945 г. URL: http://zakon3.rada.gov.ua/laws/show/995_010.

\section{Information about authors:} Voloshchuk O. T.,

$\mathrm{PhD}$ in Law, Associate Professor, Head of the Department of International and Customs Law

Chernivtsi Institute of Law of the National University "Odessa Law Academy" 7, Hryhorii Skovorodu str., Chernivtsi, 58002, Ukraine

Kolesnyk V. Yu., Assistant Professor of the Department of International and Customs Law

Chernivtsi Institute of Law of the National University "Odessa Law Academy" 7, Hryhorii Skovorodu str., Chernivtsi, 58002, Ukraine 